\title{
Efficient Shape and Material for Performance Disc Brake by Coupled Structural \& Thermal Analysis
}

\author{
R. Radha Krishna Murthy ${ }^{1}$, K. Sree Devi ${ }^{2}$ \\ ${ }^{1}$ M. Tech Student, Dept. of Mechanical Engineering, ANUCET, Nagarjuna Nagar, Guntur, India \\ ${ }^{2}$ Assistant Professor, Dept. of Mechanical Engineering, ANUCET, Nagarjuna Nagar, Guntur, India
}

\begin{abstract}
The ever increasing need of effective transportations puts automobile manufacturers in a non-avoidable situation of maintaining and improvement of safety systems. The brake system has always been one of the most critical active safety systems. Brake cooling is further an important aspect to consider for brake disc durability and performance. The motive of undertaking this project of "Efficient Shape and Material for Disc Brake by coupled Structural \& Thermal Analysis" is to study and evaluate the performance under severe braking conditions and there by assist in disc rotor shape and material. ANSYS package is a dedicated finite element package used for determining the temperature distribution, variation of stresses and deformation across the disc brake profile. In the present work, two shapes of discs available in the market for 180c.c motor cycles are considered and are individually analyzed with Grey Cast Iron and carbon Ceramic as material to determine structural deformation and stress coupled with transient thermal analysis .Based on the above results, efficient shape and material of disc is suggested.
\end{abstract}

Keywords: CATIA, ANSYS, Disc brake, Heat flux, Heat transfer coefficient, Structural analysis, Transient thermal analysis.

\section{Introduction}

\subsection{Introduction}

A brake is a device by means of which artificial frictional resistance is applied to moving machine member, in order to stop the motion of the member. In the process of performing this function, the brakes absorb either kinetic energy of the moving member and convert it into heat energy, which is dissipated to the surrounding atmosphere.

\subsection{Working Principle}

When brakes are applied, hydraulically actuated pistons move the friction pads in to contact with the disc, applying equal and opposite forces on the later. Upon releasing the brakes, the rubber-sealing ring acts as return spring and retracts the pistons and the friction pads away from the disc.

The main components of the disc brake are:

- The brake Rotor

- The caliper, which contains the piston

- The brake pads

\section{How a Disc Brake Works}

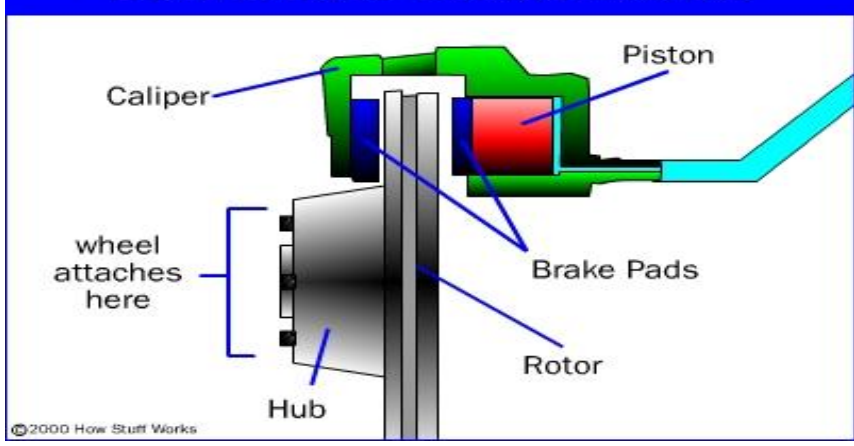

Figure 1: Working principle of disc brake

\subsection{Disc brake considerations:}

The braking power of the disc brake mostly depends on the following reasons. They are:

- Diameter of Rotor: Larger diameter rotors have more brake power for the same clamping force.

- coefficient of friction: The more the coefficient of friction at the interface, the more is the brake power.

- Material for brake rotor: The thermal diffusivity of brake rotor should be high to maintain less temperature of brake rotor.

- Speed sensitivity: As the sliding velocity between rotor and pad increases, coefficient of friction decreases, so brake power decreases.

- Pressure sensitivity: The more the clamping pressure, the more is the coefficient of friction, so the brake power increases.

- Temperature sensitivity: As the temperature of brake rotor increases, the coefficient of friction decreases, so the brake power decreases.

- Contact area of brake rotor: The more the surface area, the better would be the heat dissipation, so the brake power increases.

\subsection{Objective of the Project}

The objective is to model two Disc brakes using CATIA V5 and carry out the finite element analysis (FEA) on the prepared models using ANSYS 16. The investigation is aimed to study the efficient shape of disc brake available in the market for 180c.c motorcycles by simulating them with real braking conditions in ANSYS to find the temperature distribution, deformation and induced stresses. Later the material is changed to carbon ceramic to find out if it is any better compared to conventional grey cast iron. 


\section{International Journal of Science and Research (IJSR) \\ ISSN (Online): 2319-7064}

Index Copernicus Value (2013): 6.14 | Impact Factor (2015): 6.391

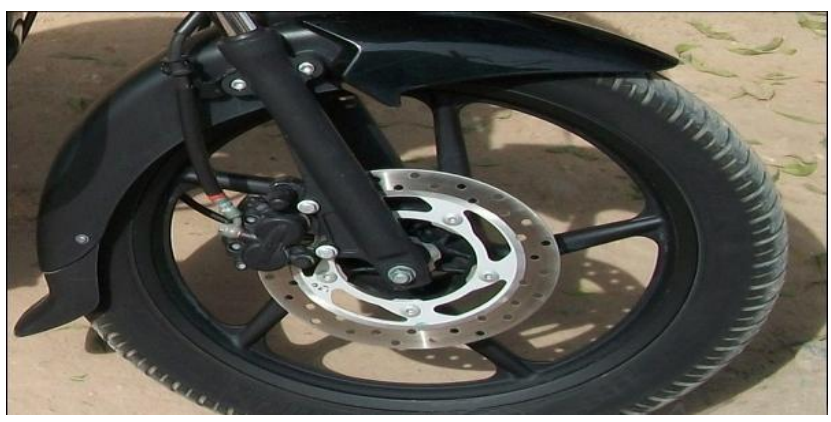

Figure 2: Circular disc brake

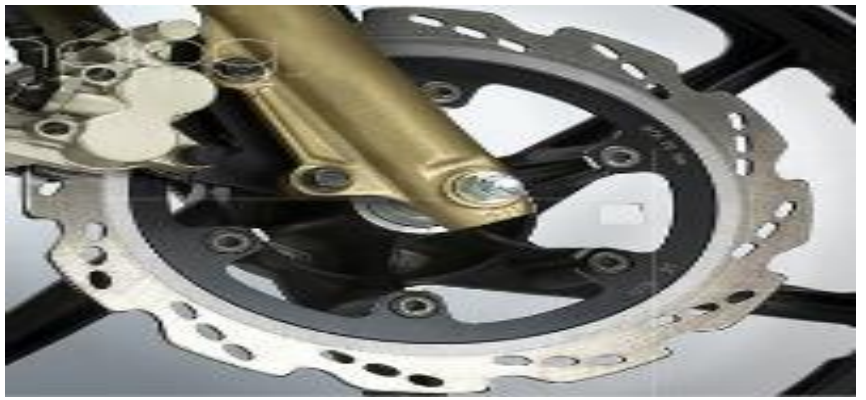

Figure 3: Petal disc brake.

\section{Design and Calculation}

\subsection{Disc Design Parameters}

Table 1: Geometrical dimensions and considerations

\begin{tabular}{|c|c|c|}
\hline Item & Circular disc & Petal disc \\
\hline Disc diameter & $260 \mathrm{~mm}$ & $270 \mathrm{~mm}$ \\
\hline Disc thickness & $5 \mathrm{~mm}$ & $5 \mathrm{~mm}$ \\
\hline Mass of disc & $1 \mathrm{~kg}$ & $1 \mathrm{~kg}$ \\
\hline Effective radius, $\mathrm{R}_{\mathrm{e}}$ & $125 \mathrm{~mm}$ & $129 \mathrm{~mm}$ \\
\hline Nature of holes & Circular & Rectangular \\
\hline No. of attachments & 5 & 6 \\
\hline Weight of automobile (kerb & $145 \mathrm{~kg}$ & $139 \mathrm{~kg}$ \\
\hline Weight of rider & $65 \mathrm{~kg}$ & $65 \mathrm{~kg}$ \\
\hline Speed during braking & $80 \mathrm{kmph}$ & $80 \mathrm{kmph}$ \\
\hline Tyre size & $90 / 90-\mathrm{R} 17 "$ & $90 / 90-\mathrm{R} 17^{\prime \prime}$ \\
\hline
\end{tabular}

\subsection{Nomenclature}

$\mathrm{F}_{1}=$ Force at brake lever $(\mathrm{N})$

$\mathrm{D}_{\mathrm{p}}=$ Diameter of piston $(\mathrm{m})$

$A_{p}=$ Cross Sectional area of piston $\left(\mathrm{m}^{2}\right)$

$\mathrm{P}=$ Pressure $(\mathrm{Pa})$

$\mathrm{D}_{\mathrm{c}}=$ Caliper piston diameter $(\mathrm{m})$

$\mathrm{A}_{\mathrm{c}}=$ Area of caliper piston $\left(\mathrm{m}^{2}\right)$

$\mathrm{F}_{\mathrm{c}}=$ Force at caliper piston $(\mathrm{N})$

$\mu=$ Coefficient of friction

$\mathrm{R}_{\mathrm{e}}=$ Effective radius $(\mathrm{m})$

$\mathrm{T}_{\mathrm{b}}=$ Braking torque $(\mathrm{N}-\mathrm{m})$

$\mathrm{A}_{\mathrm{r}}=$ Area of rubbing faces $\left(\mathrm{m}^{2}\right)$

$\mathrm{q}=$ Heat flux $\left(\mathrm{w} / \mathrm{m}^{2}\right)$

$\alpha=$ Coefficient of thermal expansion $\left(\mathrm{k}^{-1}\right)$

$\kappa=$ Thermal conductivity $\left(\mathrm{WM}^{-1} \mathrm{~K}^{-1}\right)$

$\mathrm{h}=$ Heat transfer coefficient $\left(\mathrm{WM}^{-2} \mathrm{~K}^{-1}\right)$

$\mathrm{Nu}=$ Nusselt number

$\mathrm{Re}=$ Reynolds number

$\operatorname{Pr}=$ Prandtl number

$\rho=$ Density $\left(\mathrm{Kg} \mathrm{m}^{-3}\right)$

$v=$ Poisson ratio
$\mathrm{E}=$ Youngs Modulus (Mpa)

\subsection{Material Property}

For analysis we have considered Grey cast iron and Carbon ceramic

Table 2: Material properties

\begin{tabular}{|c|c|c|}
\hline Property & Carbon ceramic & Grey cast iron \\
\hline Density & $2450 \mathrm{kgm}^{-3}$ & $7250 \mathrm{kgm}^{-3}$ \\
\hline Tensile strength & $40 \mathrm{Mpa}$ & $250 \mathrm{Mpa}$ \\
\hline Youngs Modulus & $30 \mathrm{Gpa}$ & $110 \mathrm{Gpa}$ \\
\hline Poisson ratio & 0.3 & 0.22 \\
\hline Thermal stability & $1350^{\circ} \mathrm{c}$ & $700^{\circ} \mathrm{c}$ \\
\hline $\begin{array}{c}\text { Coefficient of therma } \\
\text { expansion }\end{array}$ & $3 \times 10^{-6} \mathrm{~K}^{-1}$ & $1.1 \times 10^{-5} \mathrm{k}^{-1}$ \\
\hline Thermal conductivity & $40 \mathrm{wm}^{-1} \mathrm{k}^{-1}$ & $54 \mathrm{wm}^{-1} \mathrm{k}^{-1}$ \\
\hline Specific heat & $800 \mathrm{jkg}^{-1} \mathrm{k}^{-1}$ & $500 \mathrm{jkg}^{-1} \mathrm{k}^{-1}$ \\
\hline
\end{tabular}

\subsection{Calculations}

\subsubsection{For Circular Disc brake:}

1. Force at brake lever, $F_{1}=20 / 40 \mathrm{~N}$.

$20 \mathrm{~N}$ is during normal braking and $40 \mathrm{~N}$ during panic braking. We consider average of $30 \mathrm{~N}$.

2. Pedal ratio/leverage ratio $=5: 1$

3. Braking effort $=5 * 30 \mathrm{~N}=150 \mathrm{~N}$

4. Diameter of piston, $D_{p}=7 \mathrm{~mm}$

Area of piston, $\begin{aligned} A_{p} & =\pi / 4 * D_{p}^{*} D_{p} \\ & =3.84 \times 10^{-5} \mathrm{~m}^{2}\end{aligned}$

5. Fluid pressure, $\mathrm{P}=\mathrm{F} / \mathrm{A}_{\mathrm{p}}$

$$
=3899649 \mathrm{~Pa}
$$

As per PACALS LAW the same pressure is exerted at caliper and from the obtained pressure, the force at the caliper piston can be calculated. From the caliper force $(\mathrm{Fc})$, the braking torque is calculated.

6. Diameter of caliper piston, $D_{c}=30 \mathrm{~mm}$

Area of caliper piston, $A_{c}=\pi / 4 * D_{c} * D_{c}$

$$
=7 \times 10^{-4} \mathrm{~m}^{2}
$$

7. Force at caliper piston, $\mathrm{F}_{\mathrm{c}}=\mathrm{P}^{*} \mathrm{~A}_{\mathrm{c}}$

8. Total frictional force, $\mathrm{N}=2 * \mu * \mathrm{~F}_{\mathrm{c}}$

$$
\begin{aligned}
& =2755 \mathrm{~N} \\
& 2 * \mu * \mathrm{~F}_{\mathrm{c}} \\
& 2589 \mathrm{~N}
\end{aligned}
$$

Effective radius, $\mathrm{R}_{\mathrm{e}}=0.125 \mathrm{~m}$

9. Braking torque, $\mathrm{T}_{\mathrm{b}}=\mathrm{N} * \mathrm{R}_{\mathrm{e}}$

$$
=320 \mathrm{~N}-\mathrm{m}
$$

10. Velocity of vehicle $=80 \mathrm{kmph}=22.2 \mathrm{mps}$

Laden weight of vehicle $=200 \mathrm{~kg}$

Kinetic Energy of vehicle $=0.5 * 200 * 22.2^{2}$

$$
=49284 \mathrm{~J}
$$

Braking ratio, Front: Rear $=80: 20$

Braking KE at front wheel $=49284 * 0.8$

$$
=39427 \mathrm{~N}
$$

11. Total area of rubbing faces, $A_{r}=0.0364 \mathrm{~m}^{2}$

12. Time of braking to reach $0 \mathrm{kmph}=4 \mathrm{~s}$

13. Heat flux, $q=K E /$ Time $/ A_{r}$

$$
\begin{aligned}
& =39427 / 4 / 0.0364 \\
& =273798 \mathrm{w} / \mathrm{m}^{2}
\end{aligned}
$$

\subsubsection{For Petal Disc brake}

1. Force at brake lever, $F_{1}=20 / 40 N$.

$20 \mathrm{~N}$ is during normal braking and $40 \mathrm{~N}$ during panic

\section{Volume 5 Issue 7, July 2016 www.ijsr.net}




\section{International Journal of Science and Research (IJSR) \\ ISSN (Online): 2319-7064}

Index Copernicus Value (2013): 6.14 | Impact Factor (2015): 6.391

braking. We consider average of $30 \mathrm{~N}$.

2. Pedal ratio/leverage ratio $=5: 1$

3. Braking effort $=5 * 30 \mathrm{~N}=150 \mathrm{~N}$

4. Diameter of piston, $\mathrm{D}_{\mathrm{p}}=7 \mathrm{~mm}$

Area of piston, $A_{p}=\pi / 4 * D_{p} * D_{p}$

5. Fluid pressure, $P=F / A_{p}$

$$
=3.84 \times 10^{-5} \mathrm{~m}^{2}
$$

$$
=3899649 \mathrm{~Pa}
$$

As per PACALS LAW the same pressure is exerted at caliper and from the obtained pressure, the force at the caliper piston can be calculated. From the caliper force $(\mathrm{Fc})$, the braking torque is calculated.

6. Diameter of caliper piston, $\mathrm{D}_{\mathrm{c}}=33 \mathrm{~mm}$

Area of caliper piston, $A_{c}=\pi / 4 * D_{c} * D_{c}$

$$
=8.5 \times 10^{-4} \mathrm{~m}^{2}
$$

7. Force at caliper piston, $\mathrm{F}_{\mathrm{c}}=\mathrm{P}^{*} \mathrm{~A}_{\mathrm{c}}$

$$
=3333 \mathrm{~N}
$$

8. Total frictional force, $\mathrm{N}=2 * \mu * \mathrm{~F}_{\mathrm{c}}$

$$
=3133 \mathrm{~N}
$$

Effective radius, $\mathrm{R}_{\mathrm{e}}=0.130 \mathrm{~m}$

9. Braking torque, $T_{b}=N * R_{e}$

$$
=407 \mathrm{~N}-\mathrm{m}
$$

10. Velocity of vehicle $=80 \mathrm{kmph}=22.2 \mathrm{mps}$

Laden weight of vehicle $=200 \mathrm{~kg}$

Kinetic Energy of vehicle $=0.5 * 200 * 22.2^{2}$

$$
=49284 \mathrm{~J}
$$

Braking ratio, Front: Rear $=80: 20$

Braking KE at front wheel $=49284 * 0.8$

$$
=39427 \mathrm{~N}
$$

11. Total area of rubbing faces, $A_{r}=0.033 \mathrm{~m}^{2}$

12. Time of braking to reach $0 \mathrm{kmph}=4 \mathrm{~s}$

13. Heat flux, $q=K E / T i m e / A_{r}$

$$
\begin{aligned}
& =39427 / 4 / 0.033 \\
& =298689 \mathrm{~W} / \mathrm{m}^{2}
\end{aligned}
$$

\subsubsection{To find out heat transfer coefficient:}

For turbulent flow over a flat plate, the relation between nusselt number, reynolds number and prantyl number is given as:

$$
\begin{aligned}
& \mathrm{Nu}_{\mathrm{L}}=\mathbf{0 . 0 3 7} \mathbf{R e}^{\mathbf{0 . 8}} \mathbf{P r}^{\mathbf{0 . 3 3}} \\
& \mathrm{hL} / \mathrm{K}=0.037(\rho \mathrm{L} / \mu)^{0.8}\left(\mu \mathrm{c}_{\mathrm{p}} / \mathrm{K}\right)^{0.33} \\
& \mathrm{~h}=0.037 \mathrm{~K} / \mathrm{L}(\rho \mathrm{L} / \mu)^{0.8}\left(\mu \mathrm{c}_{\mathrm{p}} / \mathrm{K}\right)^{0.33} \\
& =98 \mathrm{WM}^{-2} \mathrm{~K}^{-1}
\end{aligned}
$$

\section{Methodology}

\subsection{Modeling in CATIA}

CATIA software is the standard in the 3D product design, featuring industry-leading productivity tools that promote one of the best practices in design while ensuring compliance regarding industry and company standards. The designing of CATIA solution allow you to design you faster than any other software. The figure shows the solid model of the disc brake by using CATIA. By taking the circular and petal disc brake dimensions we have to draw the disc brake model in CATIA.

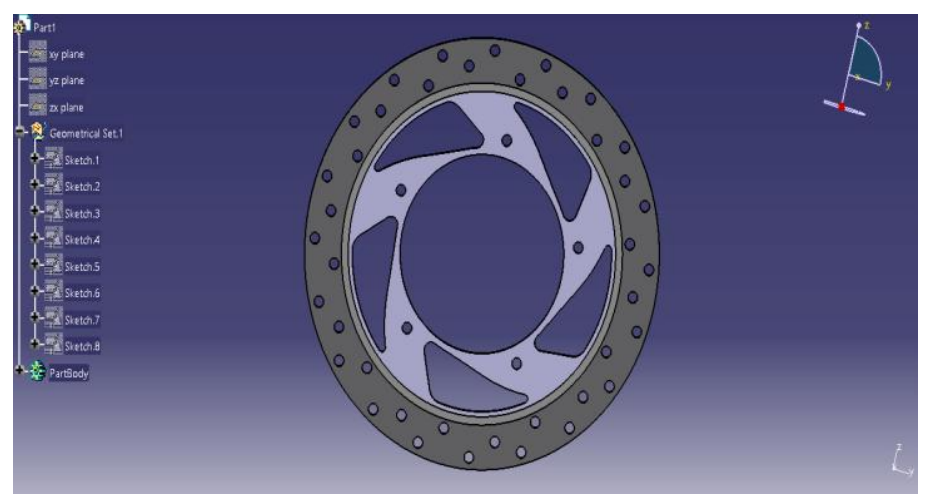

Figure 4: Circular disc brake rotor model in CATIA

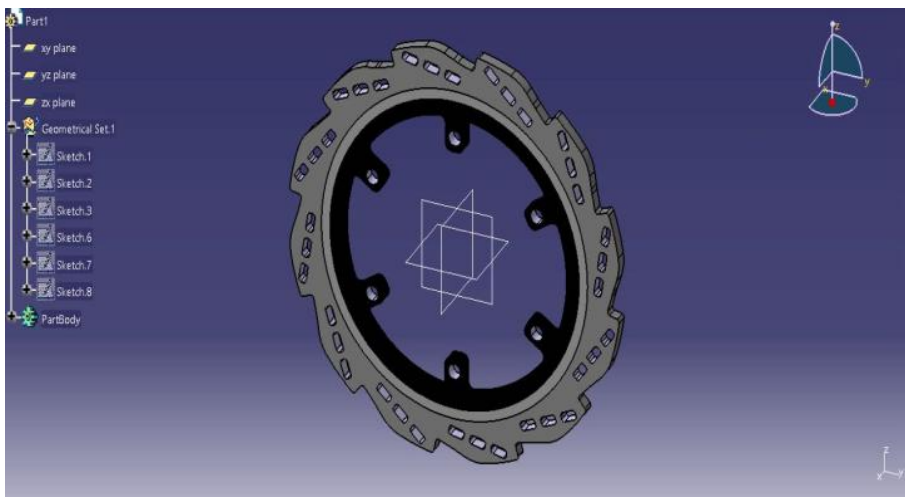

Figure 5: Petal disc brake rotor model in CATIA

The above shown figure is model drawn in the CATIA software are by using the exact Dimensions of the Disc Brake rotors with correct thickness and Dimensions.

\subsection{Analysis in ANSYS:}

Dr. John Swanson founded ANSYS Inc in 1970 with a vision to commercialize the concept of computer simulated engineering, establishing himself as one of the pioneers of Finite Element Analysis (FEM). The software implements the equations that govern the behavior of these elements and solve the problems, by creating comprehensive explanation of how the acts as whole. The results can be obtained in the form of tabular column or graphical forms.

\subsubsection{Static structural Analysis:}

A static analysis calculates the effects of steady loading conditions on a structure, while ignoring inertia and damping effects such as those caused by time varying loads. A static analysis can, however include steady inertia loads such as gravity and rotational velocity.
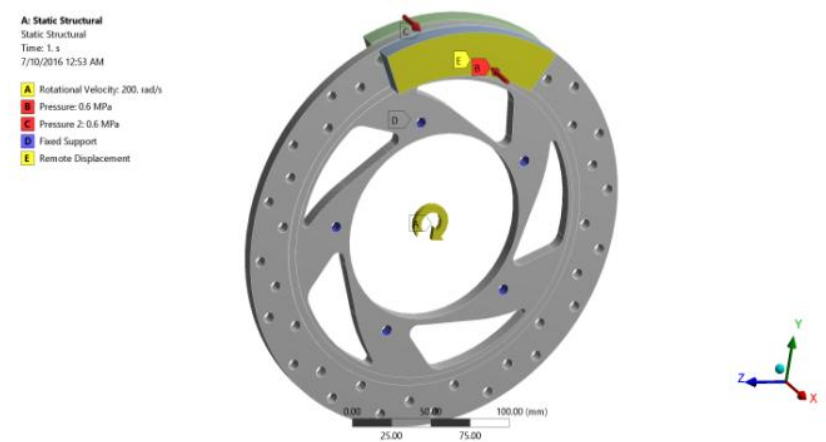

Figure 6: Structural conditions on circular disc rotor

\section{Volume 5 Issue 7, July 2016 www.ijsr.net}




\section{International Journal of Science and Research (IJSR) \\ ISSN (Online): 2319-7064}

Index Copernicus Value (2013): 6.14 $\mid$ Impact Factor (2015): 6.391
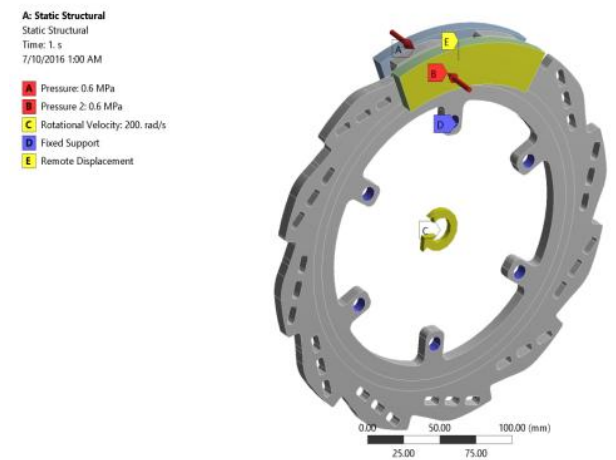

Figure 7: Structural conditions on petal disc rotor

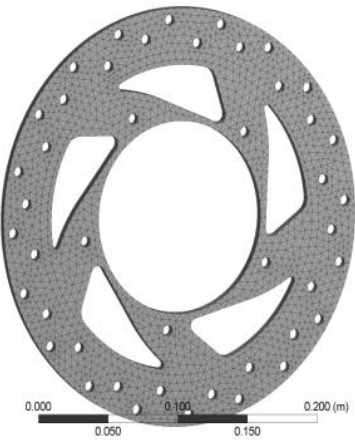

Figure 8: Meshed model of circular disc brake

Figure 8 shows the meshed model of disc brake for structural analysis process. For analysis circular disc brake was meshed using triangular surface mesher. The number of Nodes used in this meshing is 40977 and elements are 22844

\subsubsection{Thermal analysis}

A Thermal analysis calculates the temperature distribution and related thermal quantities in a system or component.

Typical thermal quantities are:

1. The temperature distributions.

2. The amount of heat lost or gained.

3. Thermal fluxes.

Types of thermal analysis:

1. A Steady State Thermal Analysis determines the temperature distribution and other thermal quantities under steady state loading conditions. A steady state loading condition is a situation where heat storage effects varying over a period of time can be ignored.

2. A Transient Thermal analysis determines the temperature distribution and other thermal quantities under conditions that vary over a period of time.

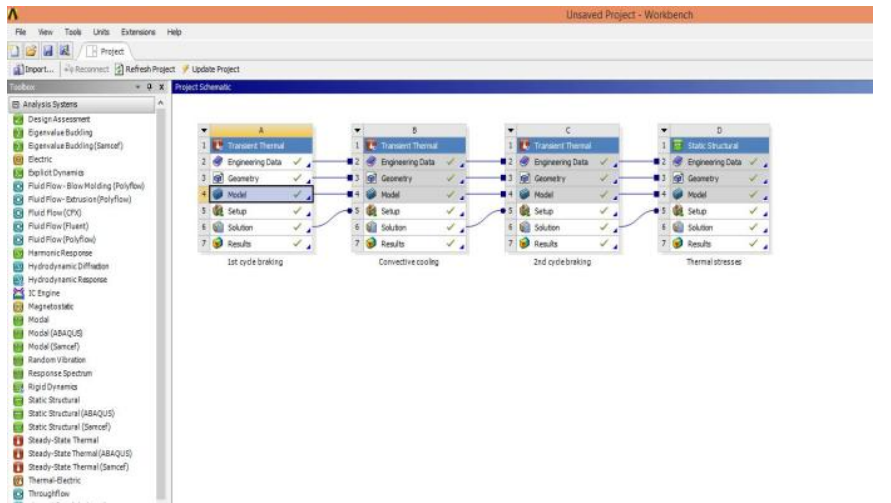

Figure 9: Thermal analysis coupled structural analysis

\section{Results}

\subsection{Structural Results}

The Equivalent von-Mises stress analysis and total deformations for both grey cast iron and carbon ceramic discs are shown below:

\subsubsection{For grey cast iron}
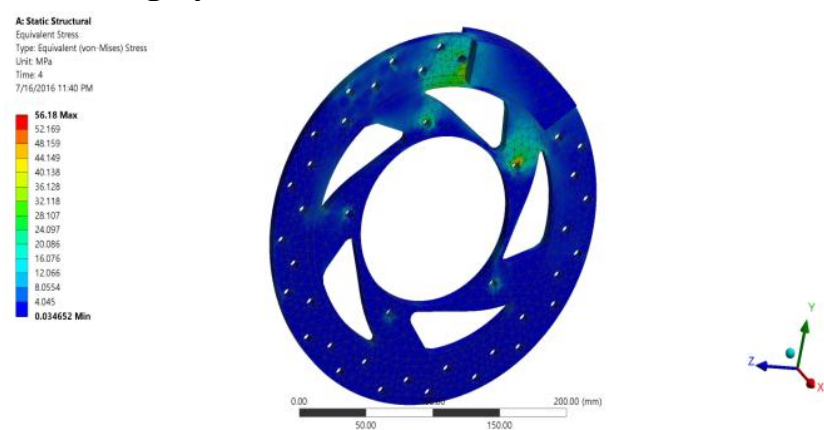

Figure 10: Stress distribution in circular disc
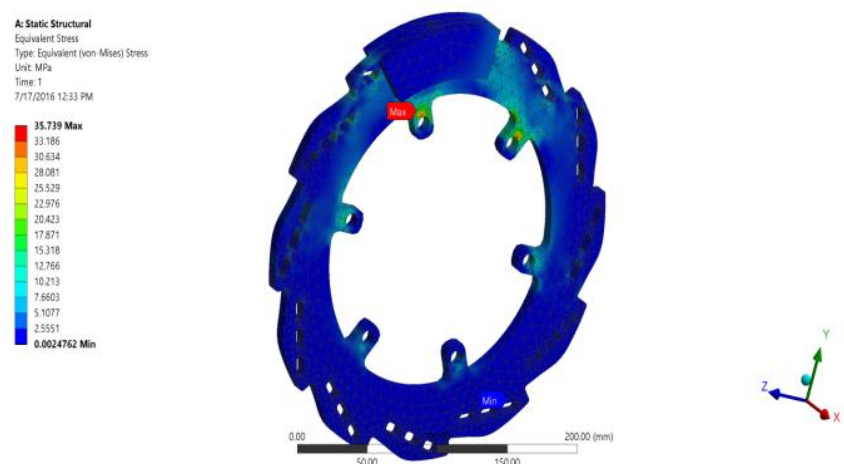

Figure 11: Stress distribution in petal disc
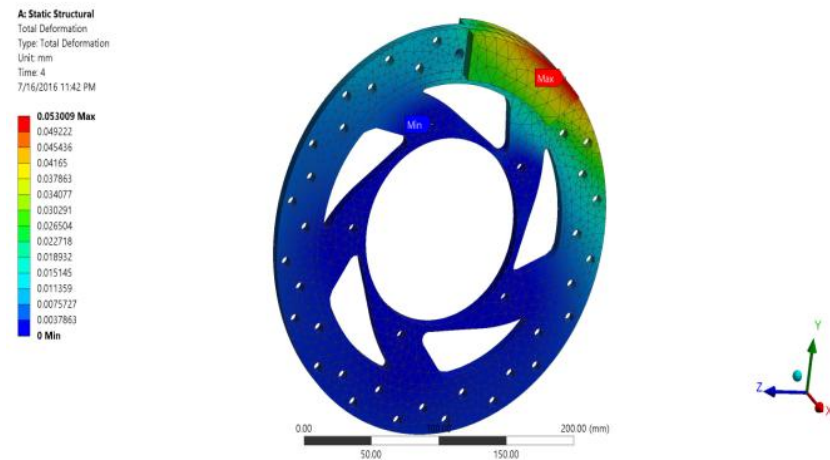

Figure 12: Total deformation in circular disc
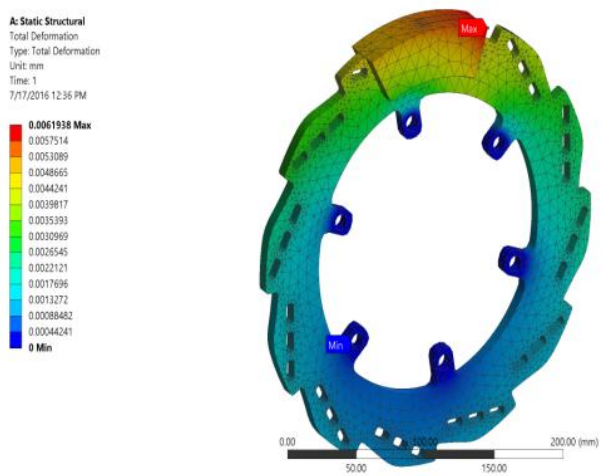

Figure 13: Total deformation in petal disc

\section{Volume 5 Issue 7, July 2016 www.ijsr.net}




\section{International Journal of Science and Research (IJSR) \\ ISSN (Online): 2319-7064}

Index Copernicus Value (2013): 6.14 | Impact Factor (2015): 6.391

\subsubsection{For carbon ceramic}

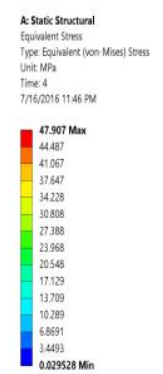

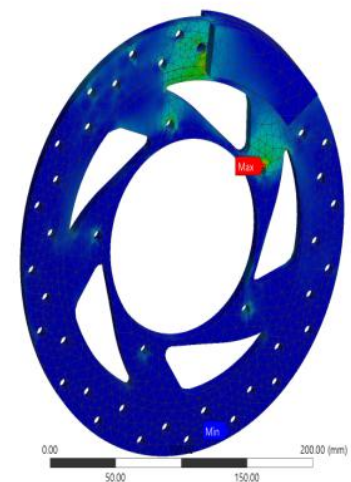

Figure 14: Stress distribution in circular disc
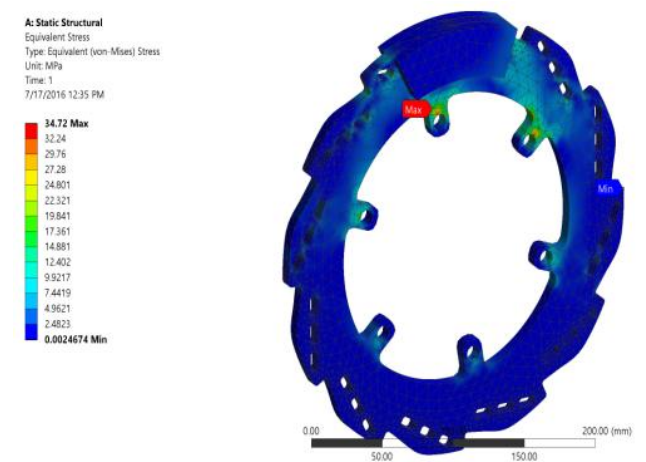

Figure 15: Stress distribution in petal disc
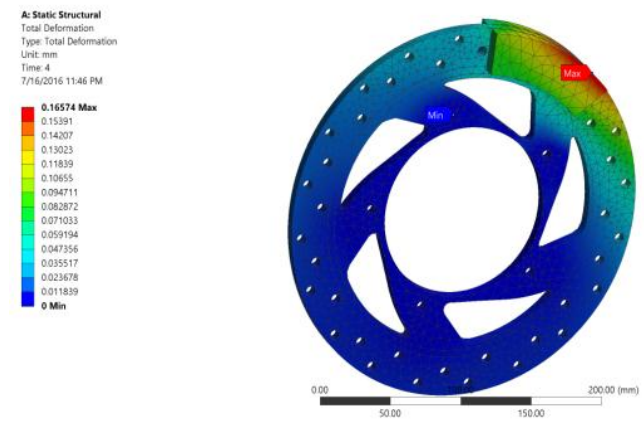

Figure 16: Total deformation in circular disc
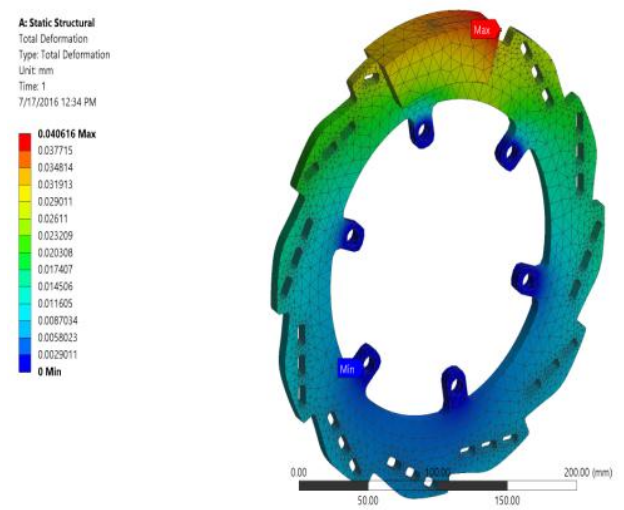

Figure 17: Total deformation in petal disc can be ignored. For thermal analysis we have calculated the following values \& find out Heat Flux during $4 \mathrm{sec}$ of braking.

\subsubsection{For grey cast iron}

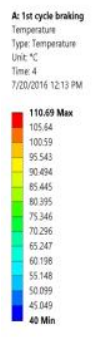

Figure 18: Temp. in circular Disc for first cycle braking
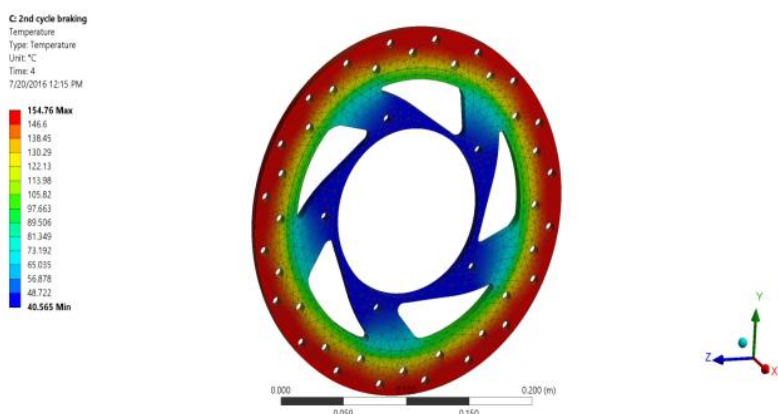

Figure 19: Temp. in circular disc for 2nd cycle braking
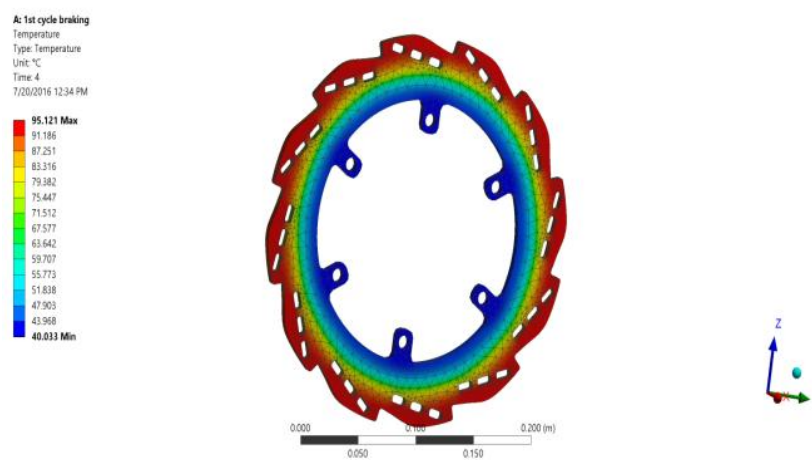

Figure 20: Temp. in petal disc for 1st cycle braking
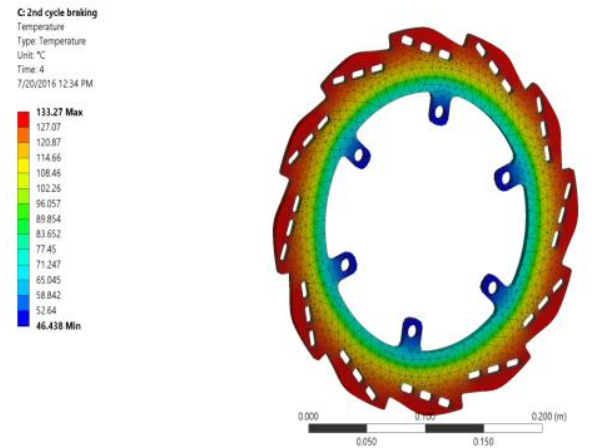

Figure 21: Temp. in petal disc for 2nd cycle braking

\subsection{Thermal Results coupled to structural analysis}

A steady state thermal Analysis also calculates the temperature distribution \& other thermal related quantities in rotor disc under steady state loading conditions. A steady state loading condition is a situation where heat storage effects varying over a period of time 


\section{International Journal of Science and Research (IJSR) \\ ISSN (Online): 2319-7064}

Index Copernicus Value (2013): 6.14 | Impact Factor (2015): 6.391
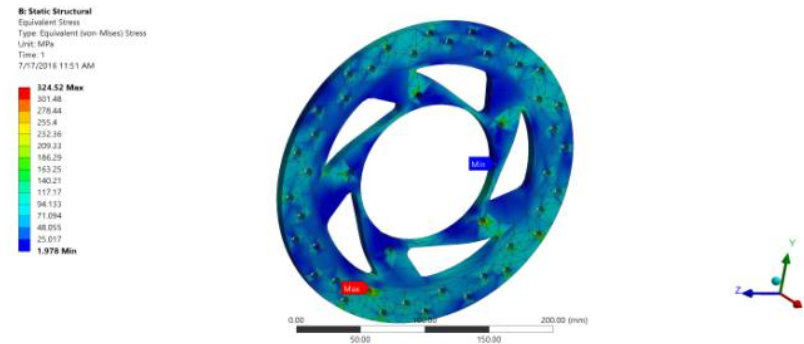

Figure 22: Thermal stress in circular disc
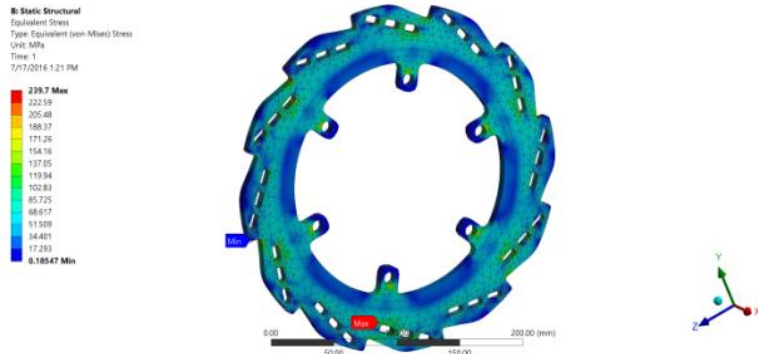

Figure 23: Thermal stress in petal disc brake

\subsubsection{For carbon ceramic}
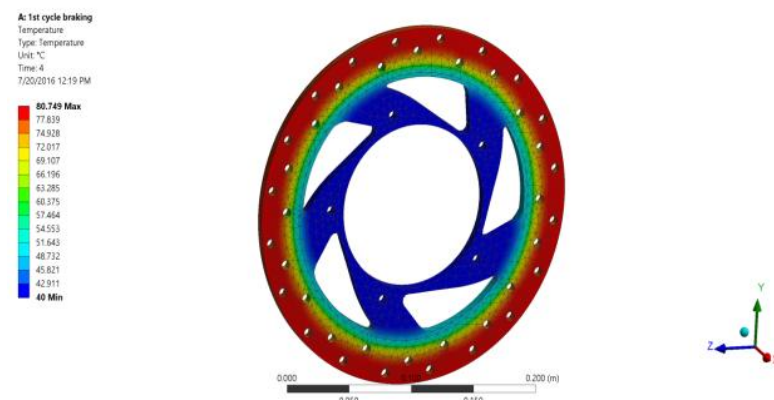

Figure 24: Temp. in circular disc for first cycle braking
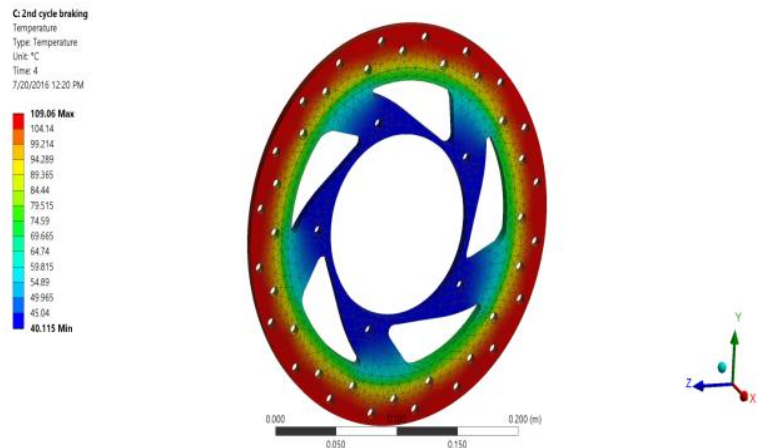

Figure 25:Temp. in circular disc for 2 nd cycle braking
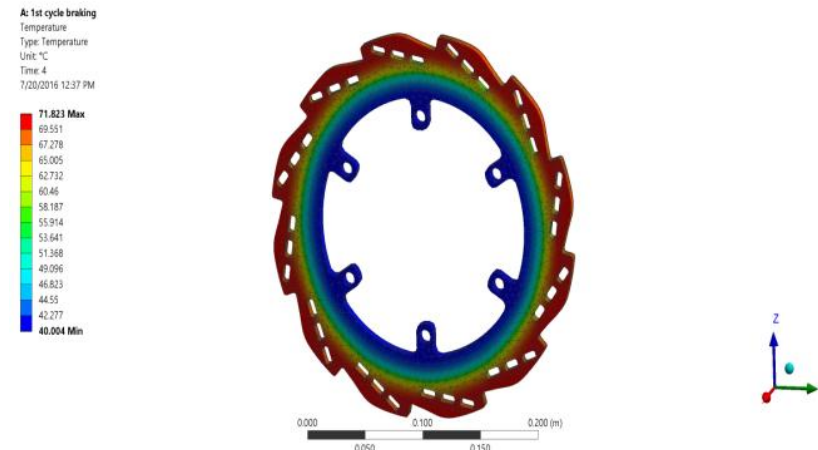

Figure 26: Temp. in petal disc for 1 st cycle braking
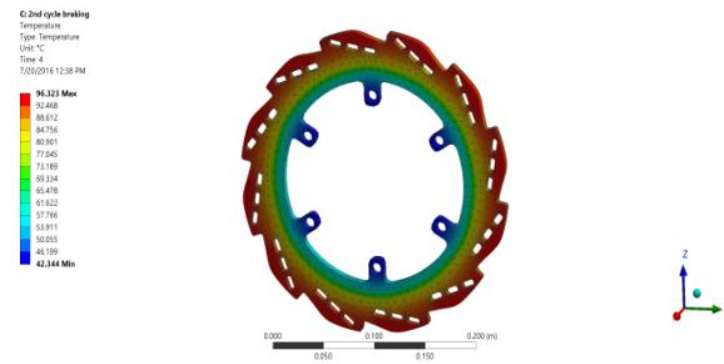

Figure 27:Temp. in petal disc for 2nd cycle braking
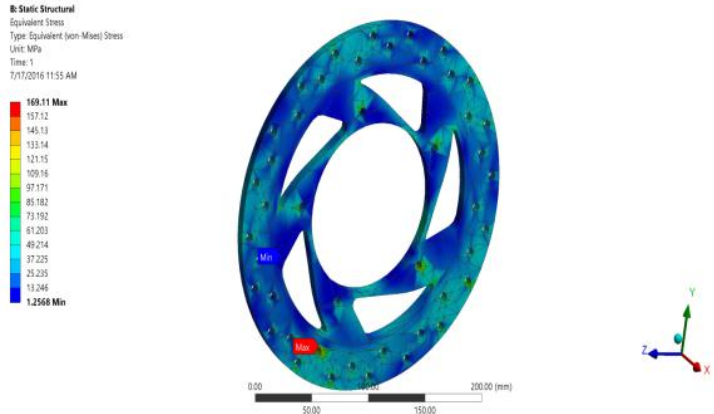

Figure 28: Thermal stress in circular disc
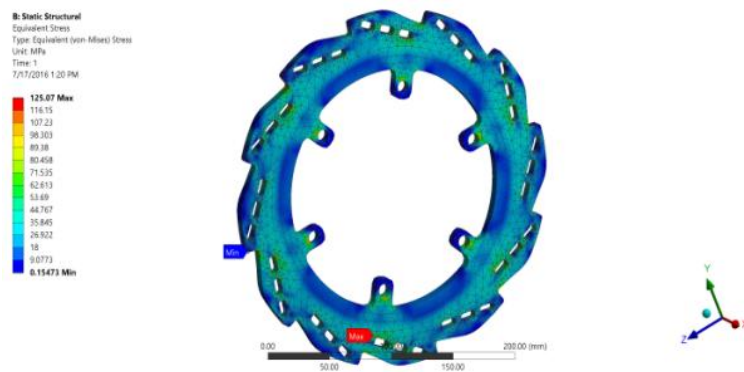

Figure 29: Thermal stress in petal disc

Table 3: Static structural results

\begin{tabular}{|c|c|c|}
\hline \multirow{2}{*}{} & \multicolumn{2}{|c|}{ Static Structural } \\
\cline { 2 - 3 } Disc & Stress, Mpa & Deformation, mm \\
GCI & 56 & 0.05 \\
\hline $\begin{array}{c}\text { Petal } \\
\text { GCI }\end{array}$ & 35.73 & 0.00619 \\
\hline Disc & & \\
CC & 47.9 & 0.16574 \\
\hline $\begin{array}{c}\text { Petal } \\
\text { CC }\end{array}$ & 34.7 & 0.040 \\
\hline
\end{tabular}

Table 4: Transient Thermal coupled structural results

\begin{tabular}{|c|c|c|c|}
\hline & \multicolumn{3}{|c|}{ Transient Thermal coupled structural } \\
\cline { 2 - 4 } & Stress, Mpa & Deformation,mm & Max Temperature, ${ }^{\circ} \mathrm{c}$ \\
\hline $\begin{array}{c}\text { Disc } \\
\text { GCI }\end{array}$ & 324 & 0.06 & 154.7 \\
\hline $\begin{array}{c}\text { Petal } \\
\text { GCI }\end{array}$ & 239.7 & 0.01 & 133.27 \\
\hline $\begin{array}{c}\text { DISC } \\
\text { CC }\end{array}$ & 169 & 0.02 & 109 \\
\hline $\begin{array}{c}\text { Petal } \\
\text { CC }\end{array}$ & 125 & 0.044 & 96.32 \\
\hline
\end{tabular}

\section{Conclusion}

From the Results obtained above, we can conclude that:

1)Petal disc has good braking performance than circular disc brake.

\section{Volume 5 Issue 7, July 2016}

www.ijsr.net 
2)The deformation and stress accumulation are very low in petal disc to circular disc.

3)Although it is a bit costly to use Carbon ceramic brake instead, the stress and braking temperature are very low than conventionally used grey cast iron.

4) Stress accumulated on the carbon ceramic is much less, which proves good wear resistance, rigid and stable braking during high speeds.

\section{References}

[1] Praveena S, Lava kumar M, Sreekanth S, "Modeling and structural analysis of disc brake", IJIRSET, ISSN-23198253, vol-1, issue-10, pg: 16501-16509, oct 2014.

[2] Rakesh jaiswal, Anupam raj jha, Anush tarki, Debaya N dej, Pawan jaiswal, Ankit Banset, Rabindra nath barman, "Structural and thermal analysis of disc brake using solidworks and ansys", IJMET, ISSN-0976-6340, vol-7, issue-1, pg: 67-77, Jan-2016.

[3] Guru murthy nathi, TN charyulu, K gowtham, P satish reddy, "Coupled structural and thermal analysis of disc brake", IJRET, issn-2319-1163, vol-1, issue-4, pg: 539553, dec-2012.

[4] Vishal asokan, Arshad mohammed gani, Vimal M, Muthu mohammad inzaman bari, "Design and analysis of reinforced composite matrix disc brake", IJERGS, ISSN-2091-2730, vol-3, issue-5, pg: 699-707, oct-2015.

[5] Ishwar gupta, gaurav saxena, vikas modi, "Thermal analysis of rotor disc of disc brake of baja sae $2013 \mathrm{car}$ through finite element analysis", IJERA, ISSN-22489622, Pg: 324-329, March-2014.

[6] Ingale SP, Prof. patel A.Z, prof. ghalake A.B, "Advanced transient thermal and structural analysis of disc brake by using ansys in two wheeler", IJIRET, ISSN-2394-3696.

[7] Swapnil R. abhang, D.P. Bhaskar, "Design and analysis of Disc brake", IJETT, ISSN-2231-5381, vol-8, pg: 165167, feb-2014.

[8] K. Mahadevan, K. Balaveera reddy, "Design data hand book".

[9] C.P. Kothandaraman, S. Subramanyan, "Heat and mass transfer data book".

[10] Karim Nice, "How disc brakes work", Available: http://auto.howstuffworks.com/auto-parts/brakes/braketypes/disc-brake.htm. 